УДК 37.034: 159

DOI: $10.35619 /$ iiu.v1i10.164

Косарєва Оксана

кандидат педагогічних наук, доцент, доцент кафедри педагогіки та психології (дошкільної та корекційної) імені проф. Т. І. Поніманської Рівненського державного гуманітарного університету, м. Рівне, Україна ORCID: 0000-0001-6905-905X, e-mail: okosaryeva@ukr.net

\title{
ХАРАКТЕРНІ ПОЗИЦІЇ ЧОЛОВІКІВ І ЖІНОК У СТАВЛЕННІ ДО ДІТЕЙ ДОШКІЛЬНОГО ВІКУ
}

Анотація. В даній статті висвітлені результати емпіричного дослідження відмінностей у позиціях чоловіків і жінок у ставленні до дітей дошкільного віку, а також результати вивчення батьківсько-дитячої взаємодії. 3 метою оцінки особливостей батьківсько-дитячої взаємодії в дослідженні використовувалась методика «Взаємодія батьки-дитина» I. Марковської. Для оцінки ступеня та модальність значущості матері та батька для кожної дитини використовувався редукований варіант методики «Сімейний тест стосунків» Д. Антоні та Е Бене.

Як відомо, для більшості чоловіків характерні такі позиції у взаєминах з дітьми, як вимогливість, контроль поведінки дитини та емоційна дистанція у взаєминах 3 дитиною; у матерів частіше проявляється тривожність за дитину, вони характеризуються меншою послідовністю, нестабільністю у взаєминах 3 дітьми. Результати «Сімейного тесту ставлення» свідчать, що більша частина дітей проявляє позитивні почуття i до матерів, і до батьків. Однак відсоток дітей, що мають амбівалентне ставлення до батьків, перевищує кількість дітей, що проявляє амбівалентні почуття до матері. Якщо ставлення, яке дитина отримує від матері, переважно позитивне, то сприйняття дітьми ставлення батьків менш сприятливе: разом 3 позитивним існує і амбівалентне сприйняття почуттів, адресованих дитині від батька.

Ключові слова: позиції батьків, дитячо-батьківська взаємодія, сімейні стосунки.

Постановка проблеми. Сім'я $є$ одним 3 найважливіших детермінант становлення та розвитку особистості. Батьки відіграють важливу роль у формуванні Я-концепції, хоча, оточуючі також можуть впливати на розвиток здібностей дитини, пріоритет батьків у вихованні особистості виявляється безперечним. Психологічний клімат, який створюють батьки, має для дитини життєво важливе значення. Якщо клімат стає нестерпним для дитини, їі нестійка психіка не витримує і дитина починає хворіти. Батьки постійно впливають на власний сімейний клімат, в стані його змінити та зробити його сприятливим для своєї дитини. Батьки в змозі забезпечити дитині любов і підтримку в сім’ї, зробити так, щоб вона завжди знала, що потрібна їм. Важливіше за все, батькам не втратити довіру дитини, оскільки настане момент, коли ӥй знадобиться допомога та підтримка. (Бондарчук, 2001).

Сім'я являє собою єдність близьких людей, засновану на взаємодопомозі, взаєморозумінні, взаємній відповідальності, вона забезпечує психологічну захищеність і емоційний контакт. Члени сім’ї, вступаючи один 3 одним в різні форми взаємодії та взаємостосунків, деформація або відсутність яких відбиваються на розвитку особистості дитини. Сім'я для дитини, за своїм змістом, - це, перш за все, ії батьки, брати та сестри, бабусі та дідусі, інші родичі. У сім'ї дитина реалізує потребу та можливість бути любимою та захищеною. Уявлення дитини про сім'ю не завжди співпадають 3 реальною ситуацією, а також 3 оцінкою ситуації дорослими. 
(Алєксєєнко, 2002).

Особливості соціально-психологічних обставин та взаємовідносин в сім’і визначають вплив батьків - центру системи сімейних взаємостосунків. У кожній сім'ї формується певна система взаємостосунків, яка передбачає застосування припустимих та неприпустимих прийомів впливу на дитину. Система батьківських впливів і тактика ïх застосування не завжди усвідомлюються, впорядковуються та цілеспрямовано використовуються батьками.

Аналіз останніх досліджень 3 проблеми. Сімейній проблематиці присвячені дослідження Т. Буленко, Т. Говорун, В. Зацепіна, 3. Кісарчук, М. Обозова та інших. Проте ця тема не втрачає своєї актуальності, особливо 3 урахуванням сучасних суспільних трансформацій в Україні, що торкнулися й сім'ї.

Відомо, що порушення сімейних взаємин патогенно впливає на розвиток особистості дитини. При цьому однією з основних причин, що сприяють формуванню психопатологічних рис особистості, зазвичай виступає неправильне виховання, хибні позиції батька чи матері. Вони можуть проявлятися в надмірній вимогливості, раціоналізмі, емоційному відторгненні дитини, в непомірній афектації, підвищеній тривожності тощо.

Вплив позиції батьків на способи поведінки та розвиток дитини було проаналізовано в роботах О'Коннера, а відтак робота по узагальненню цих даних проведена В. Аверіним (Аверін, 2006). Аналіз літератури свідчить, що більшість авторів виділяють такі параметри взаємодії батьків з дитиною: автономія - контроль (Е. Шеффер, Р. Бел, С. Броуді, Е. Маккобі, В. Шутц); відторгення - прийняття (А. Рое, М. Сегелман, О. Захаров, Д. Ісаєв, А. Варга); вимогливість (Е. Маккобі, О. Коннер, П. Слатер); ступінь емоційної близькості (Дж. Боулбі, В. Шутц, Г. Хоментаускас); суворість (Е. Маккобі, П. Слатер); непослідовність - послідовність (С. Броуді, Е. Маккобі, У.-Х. Севелл, О. Захаров).

Мета статті - виявлення відмінностей у позиціях чоловіків і жінок щодо дітей дошкільного віку та визначення позиції дитини стосовно членів сім’ї, (зокрема, вибірковість у ставленні до батька чи матері), якісно та кількісно оцінити почуття, які дитина відчуває до них.

Виклад основного матеріалу дослідження. 3 метою оцінки особливостей батьківсько-дитячої взаємодії в нашому дослідженні використовувалась методика «Взаємодія батьки-дитина» (ВБД), (Марковська, 2002), яка дозволяє дослідити такі параметри батьківсько-дитячої взаємодії: вимогливість, суворість, контроль, емоційна близькість, прийняття, співробітництво, тривожність, послідовність, конфронтація, задоволеність. Опитувальник складається 360 питань, кожне 3 яких передбачає оцінку ступеня погодження 3 ним за п'ятибальною системою. Питання пропонувалися окремо матері та батькові. Оцінка показників батьківсько-дитячої взаємодії проводилася за 10ма шкалами, що мають дихотомічно сформульовані назви. Відповіді батьків заносились у відповідні бланки. Після цього підраховувалась загальна кількість балів за кожною шкалою, при цьому враховувались прямі та зворотні твердження. Для інтерпретації даних опитувальника ВБД користувались результатами процентальної стандартизації, представленою І.Марковською.

На другому етапі нашого дослідження ми визначали оцінку ступеня та модальність значущості матері та батька для кожної дитини. Для реалізації цієї мети використовувався редукований варіант методики СТС («Сімейний тест стосунків») Д. Антоні та Е. Бене (Лідерс, Анісімова, 1993). Методика є проективною і дозволяє визначити позицію дитини відносно членів сім'ї, якісно та кількісно оцінити почуття, які дитина відчуває до них.

Процедура проведення включала декілька етапів. На першому етапі пропонувалося дітям намалювати малюнок сім'і, одночасно задавалися запитання про те, хто живе разом $з$ дітьми, які ролі в сім’ї виконують ті персонажі, які зображені на малюнку. У своїй роботі ми користувалися принципами аналізу структури малюнка сім’ї. 
На наступному етапі проводився власне сам тест СТС. Процедура обстеження максимально була наближена до ігрової ситуації. Дитині пропонувалося пограти в пошту. Ми показували набір листів, які дитина в ролі поштаря повинна «рознести» своїм членам сім'ї, при цьому оговорювалося, що можна використовувати лише простір намальованого малюнка сім'ї, розкладаючи біля кожної фігури купки листів. Дитині пояснювалось, що тільки вона сама може вирішити, яке звертання кому пасує (при цьому підкреслювалось, що самому собі також можна послати лист). Також відбувалось знайомство з фігурою Ніхто - намальованою на окремому аркуші фігурою чоловіка в шляпі та пальто: йому потрібно посилати листи, які не підходять нікому.

Картки пропонувалися в такому порядку, щоб позитивні та негативні реакції розподілялись рівномірно, в кінці були дані висловлювання позитивної спрямованості.

Як наслідок, кожен член модифікованої дитиною сім’ї отримує свій паттерн емоційного ставлення, який містить перерахований вище набір почуттів. Загальна значущість тієї чи іншої людини визначається числом звернень, що були відправлені дитиною. Чим більше звернень у порівнянні 3 іншими членами сім'ї, тим вища значущість. Для оцінки загальної значущості звернення з негативними та позитивними почуттями узагальнюються. Для оцінки емоційного відтінку значущості розглядається окремо число позитивних та негативних почуттів, які були відправлені кожному члену сім'ї. Для нашого дослідження найбільший інтерес мали дорослі члени сім’ї, зокрема, мати та батько.

Важливо розуміти, що значущість зовсім не обов'язково повинна мати позитивний відтінок: дитина може настільки боятися та (або) не любити когось 3 дорослих, що перед цими почуттями позитивні емоції щодо інших членів сім'ї будуть мати інший відтінок.

У такий спосіб, була отримана інформація не тільки про ступінь, але і про модальність (знак) емоційної значущості для дитини кожного члена сім'ї. Методика дає можливість отримати, у разі потреби, більш широке коло інформації: про сприйняття дитиною структури сім’ї, про рівень егоцентризму та аутоагресії та, навіть, про деякі захисні механізми, що використовуються дитиною.

У дослідженні брало участь 58 дітей старшого дошкільного віку та їх батьки (96 чоловік). Аналіз результатів методики ВБД свідчить, що за першою шкалою «вимогливість» властива більшості чоловікам (60\%) і лише 30-ти відсоткам жінок. А це значить, що чоловіки очікують більшого рівня відповідальності від своїх дітей, висувають більше претензій та вимог до них.

Показники другої шкали «суворість» також свідчать про те, що така тенденція більш властива для чоловіків, ніж для жінок (відповідно $55 \%$ та $25 \%$ $\varphi^{*}=2,98$ $(\mathrm{p}<0,001))$. Чоловіки більш жорсткіші у взаєминах 3 дітьми, частіше використовують різного роду покарання, тому для більшості чоловіків властивий суворіший стиль батьківсько-дитячої взаємодії.

Відмінностей у показниках третьої шкали «контроль» майже не було виявлено. В основному для більшості батьків чоловічої та жіночої статі характерна контролююча поведінка щодо дитини, яка проявляється у надмірній опіці, прагненні приймати за неї рішення, попереджати будь-які труднощі у житті дитини.

Результати методики за четвертою шкалою свідчать, що для переважної більшості чоловіків (60\%) характерна емоційна дистанція у стосунках 3 дітьми, у жінок ця тенденція проявляється в меншій мірі $(25 \%)\left(\varphi^{*}=3,47(\mathrm{p}<0,001)\right)$.

Різниці показників за п'ятою шкалою майже не виявлено, в основному для більшості батьків (90\%) характерне прийняття своєї дитини.

За шкалою «співробітництво» ми отримали такі результати: більшість батьків (84,9\%) (відмінностей між батьком та матір'ю не спостерігається) не мають спільних 3 дитиною видів діяльності, у яких враховувалися б інтереси дитини, проявлялась здатність встановлювати взаємини рівності та партнерства. 
Результати сьомої шкали «тривожність» свідчать, що цей прояв характерний переважно для жінок (20\%), у чоловіків він майже не спостерігається (5\%), вони спокійніші за свою дитину. Загальновідомо, що за психологічною консультацією звертаються, як правило, матері, при цьому нерідко проблеми 3 дитиною здаються батькам надуманими і такими, що не заслуговують уваги.

Восьма шкала «послідовність» оцінювала ступінь передбачуваності батьківської поведінки стосовно своєї дитини, стабільність ставлення до неї та системи вимог, що висуваються. Але цей параметр характерний лише для $25 \%$ чоловіків та для $15 \%$ жінок.

Показники дев'ятої шкали «виховна конфронтація» відображають ступінь узгодженості чи неузгодженості у дорослих членів сім'ї виховних стратегій та наявність конфліктів між ними 3 цього приводу. Результати нашого дослідження демонструють, що виховна конфронтація проявляється у $39,8 \%$ сімей, і це є серйозним дестабілізуючим фактором для розвитку особистості дитини.

Аналіз результатів десятої шкали «задоволеність дитячо-батьківськими стосунками» свідчить, що 60,1\% батьків не влаштовує загальна система взаємин, що склалися між ними та дитиною. Відмінностей між батьками та матерями не виявлено.

Результати другого етапу нашого дослідження за методикою СТС переконують, що для дитини більш значимі стосунки з матір'ю (61\%), ніж з батьком (39\%).

При цьому зафіксовано різницю у ставленні дітей до кожного з батьків (таблиця 1).

Таблиця 1

\section{Ставлення дітей до батьків за модифікованим варіантом «Сімейного тесту ставлень» $(\%)$}

\begin{tabular}{|l|c|c|c|c|}
\hline \multicolumn{1}{|c|}{ Вид ставлення } & \multicolumn{2}{|c|}{ відправлене дитиною } & \multicolumn{2}{c|}{ адресоване дитині } \\
\hline Знак ставлення & до батька & до матері & до батька & до матері \\
\hline Позитивне & 69 & 80 & 47 & 86 \\
\hline Амбівалентне & 25 & 10 & 41 & 14 \\
\hline Негативне & 6 & 0 & 12 & 0 \\
\hline
\end{tabular}

Таблиця 1 демонструє, що більша частина дітей проявляє позитивні почуття і до матерів, і до батьків. Однак відсоток дітей, які мають амбівалентне ставлення до батьків, перевищує тих, хто проявляє амбівалентні почуття до матері. Якщо ставлення, яке дитина отримує від матері, переважно позитивне в контрольній групі, то сприйняття дітьми ставлення батьків менш сприятливе: разом 3 позитивним існує і амбівалентне сприйняття почуттів, адресованих дитині від батька. За цих умов дітей, котрі приймають позитивні почуття батька до себе, статистично менше порівняно зі схожим ставленням матері, але достовірно більше тих дітей, які приймають амбівалентне ставлення до себе батька порівняно зі схожим ставленням матері.

Результати тестування свідчать також про те, що крім батьків найбільш значущими фігурами для дітей із багатодітних сімей можуть виступати брат або сестра.

Якщо матерів як значущу особу єдині діти та діти, котрі мають брата чи сестру, обирають статистично однаково часто, то доля дітей, які обирають батька в однодітних сім'ях, статистично більша, ніж доля осіб, які обирають батька в багатодітних сім'ях.

Отримані данні дозволяють передбачити, що в структурі багатодітної сім'ї батько відтісняється на периферію, а на перший план, разом з матір'ю, виходять стосунки 3 братом або сестрою.

Висновки і перспективи подальших розвідок. Узагальнюючи результати проведеного дослідження, можна зробити висновки, що у позиціях обох батьків щодо дітей існують відмінності. Так, для більшості чоловіків характерні такі позиції у взаєминах з дітьми, як вимогливість, контроль поведінки дитини та емоційна дистанція у взаєминах з дитиною; у матерів частіше проявляється тривожність за дитину, вони 
характеризуються меншою послідовністю, нестабільністю у взаєминах 3 дітьми. Результати «Сімейного тесту ставлення» свідчать, що мати частіше, ніж батько, проявляє позитивні реакції до дитини, i, відповідно, від батька дитина частіше отримує реакції негативного характеру.

Батьки сприймаються дитиною у порівнянні 3 матір'ю як менш турботливі та люблячі. Найбільш значущою фігурою із батьківської пари для дитини є матір.

Перспективу нашого подальшого дослідження ми вбачаємо в розробці корекційної програми, основна мета якої полягатиме в сприянні та розвитку стосунків партнерства та співробітництва батьків з дитиною дошкільного віку.

\section{СПИСОК ВИКОРИСТАНИХ ДЖЕРЕЛ}

Бондарчук, О. (2001). Психологія сім'ї: курс лекцій. Київ: МАУП, 96 с.

Аверин, В. (2006). Психология детей и подростков: монография. Санкт-Петербург: Питер. 379 с.

Алєксєєнко, Т. (2002). Сходинки гуманних взаємин батьків і дітей. Дитячий садок. № 24. С. 3-24.

Марковская, И. (2002). Тренинг взаимодействия родителей с детьми. СанктПетербург: ООО Издательство «Речь». 150 с.

Лидерс, А., Анисимова, И. (1993). Детский тест «Диагностика эмоцииональных отношений в семье» (Методическое руководство). Москва. $31 \mathrm{c}$.

\section{REFERENCES}

Bondarchuk. O. (2001). Psykholohiia simi: kurs lektsii [Family Psychology: A Lecture Course]. Kyiv: MAUP. 96 s. (in Ukrainian)

Averin. V. (2006). Psikhologiya detey $i$ podrostkov: monografiya [Psychology of Children and Adolescents: monograph]. Sankt-Peterburg: Piter. 379 s. (in Russian)

Alieksieienko, T. (2002). Skhodynky humannykh vzaiemyn batkiv i ditei. [Steps of Humane Parent-child Relationships]. Dytiachyi sadok. No 24. S. 3-24. (in Ukrainian)

Markovskaya. I. (2002). Trening vzaimodeystviya roditeley $s$ detmi [Parent-child Interaction Training]. Sankt-Peterburg: OOO Izdatelstvo "Rech". 150 s. (in Russian)

Liders. A. \&. Anisimova. I. (1993). Detskiy test "Diagnostika emotsionalnykh otnosheniy v semye" (Metodicheskoye rukovodstvo) [Children's Test "Diagnosis of Emotional Relations in the Family" (Methodical guide)]. Moskva. 31 s. (in Russian)

\section{CHARACTERISTIC POSITIONS OF MEN AND WOMEN FOR PRESCHOOL CHILDREN}

Oksana Kosarieva

Candidate of Pedagogical Sciences, Associate Professor, Associate Professor at the Department of Pedagogy and Psychology (Preschool and Correctional) named after Professor T.Ponimanska,

Rivne State University for the Humanities,

Rivne, Ukraine ORCID: 0000-0001-6905-905X, e-mail: okosaryeva@ukr.net

\footnotetext{
Abstract.This article deals with the results of 7-years empirical experiment on the differences in the attitude of men and women in preschool children, as well as the results of parent-child interaction studies. In order to evaluate the features of parent-child interaction in the learning, I. Markovskaya's method "Parent-child interaction" was implemented. This method allowed to investigate the following parameters of parent-child cooperation: demanding, strictness, control, emotional closeness, acceptance, cooperation, anxiety, consistency, confrontation, satisfaction.
} 
In order to assess the degree and modality of mother and father significance for each child, a reduced version of the "Family Relationship Test" by D. Anthony and E. Ben has been implemented. The technique is projective and allows determine the attitude of the child to the family, qualitatively and quantitatively evaluate the feelings that a child feels toward them.

So, the majority of men are characterized by positions in relationships with children, such as demanding, controlling the behavior of the child and emotional distance in dealing with the child; mothers are more likely to have anxiety than a child; they are characterized by less consistency, instability in relationships with children.

The results of the Family Attitude Test showed that the majority of children have positive feelings toward both parents. However, the percentage of children who have an ambivalent attitude toward their father exceeds the number of children who show ambivalent feelings about the mother.

If the attitude that the child receives from the mother is predominantly positive, the child's perception of the father's attitude is less favorable: along with the positive, there is an ambivalent perception of the feelings addressed to the child by the parent. Under these conditions, children who adopt a father's positive feelings toward themselves are statistically less compared to their mother's similar attitudes, but significantly more children who adopt an ambivalent attitude toward their father compared to their mother's similar attitudes.

Keywords: father and mother positions, parent-child relationships, family relationships.

Стаття надійшла до редакиії 25.09.2019 p. 